\title{
Pengaruh cabe rawit terhadap gambaran histopatologik lambung tikus Wistar yang diinduksi aspirin
}

\author{
${ }^{1}$ Abel T. Bawulele \\ ${ }^{2}$ Lily Loho \\ ${ }^{2}$ Poppy Lintong
}

\author{
${ }^{1}$ Kandidat Skripsi Fakultas Kedokteran Universitas Sam Ratulangi Manado \\ ${ }^{2}$ Bagian Patologi Anatomi Fakultas Kedokteran Universitas Sam Ratulangi Manado \\ Email: abelbawulele@gmail.com
}

\begin{abstract}
Cayenne pepper (Capsicum frustescens L ) is commonly in daily food. This study aimed to determine the effect of cayenne pepper to histopathological changes in gaster of Wistar rats induced by aspirin. This was an experimental study. Subjects were Wistar rats consisted of 5 rats as the negative control and 20 rats as the treatment group. Group A, the negative control group, was untreated; group B was treated with aspirin $21 \mathrm{mg} /$ day for 10 days; group C was treated with aspirin $21 \mathrm{mg} /$ day for 10 days together with cayenne pepper $84 \mathrm{mg}$ once daily; group D was treated with aspirin $21 \mathrm{mg} /$ day for 10 days followed by cayenne $84 \mathrm{mg}$ twice daily; and group $\mathrm{E}$ was treated with aspirin $21 \mathrm{mg} /$ day for 10 days and then was untreated for 3 days. The histopathological changes in group $C$ showed a lot of inflammatory cells and erosion of gastric mucosa epithelium compared to group B, D, and E. Group D also showed inflammatory cells but no erosion as in group C. Group E had less inflammatory cells than group B, C, and D. Conclusion: Administration of aspirin $21 \mathrm{mg} / \mathrm{kg}$ BW for 10 days led to acute gastritis in Wistar rat. Administration of aspirin together with cayenne $84 \mathrm{mg} / \mathrm{day}$ led to acute gastritis and erosion of gastric mucosa epithelium. However, administration of cayenne pepper $168 \mathrm{mg} /$ day after aspirin led to acute gastritis without erosion
\end{abstract}

Keywords: pepper, gaster, aspirin

\begin{abstract}
Abstrak : Cabe Rawit (Capsicum frustescens L.) banyak dijumpai dalam makanan sehari-hari. Penelitian ini bertujuan untuk mengetahui pengaruh pemberian cabe rawit terhadap gambaran histopatologik lambung tikus wistar yang diinduksi aspirin. Jenis penelitian ialah eksprimental. Subjek penelitian ialah tikus wistar, yang dibagi atas: 5 ekor untuk kontrol negatif dan 20 ekor untuk perlakuan. Kelompok A (kontrol negatif) tidak diberi perlakuan; kelompok B diberikan aspirin 21mg/hari selama 10 hari; kelompok C diberikan aspirin $21 \mathrm{mg}$ /hari selama 10 hari bersama cabe rawit $84 \mathrm{mg}$ sekali sehari; kelompok D diberikan aspirin $21 \mathrm{mg} /$ hari selama 10 hari kemudian dilanjutkan pemberian cabe rawit $84 \mathrm{mg}$ selama 3 hari 2 kali sehari; dan kelompok E diberikan aspirin 21mg/hari selama 10 hari kemudian tidak diberi perlakuan selama 3 hari. Hasil penelitian menunjukkan bahwa pada kelompok C terlihat banyak sel-sel radang disertai erosi epitel mukosa lambung dibanding dengan kelompok B, D, dan E. Pada kelompok D pemberian aspirin dilanjutkan dengan cabe rawit dosis 2 kali sehari masih terdapat sel-sel radang tetapi tidak terjadi erosi seperti pada kelompok C. Kelompok E memiliki sel-sel radang yang lebih sedikit dibandingkan kelompok B, C, dan D. Simpulan: Pemberian aspirin 21mg/hari selama 10 hari menyebabkan gastritis akut pada tikus wistar. Pemberian aspirin bersama cabe rawit $84 \mathrm{mg} /$ hari menyebabkan gastritis akut erosi sedangkan pemberian cabe rawit 168mg/hari setelah diberi aspirin menyebabkan gastritis akut tanpa erosi.
\end{abstract}

Kata kunci: cabe rawit, lambung, aspirin 
Faktor-faktor yang dapat menyebabkan gangguan lambung antara lain obat-obatan, alkohol, rokok dan stres berat. Aspirin tergolong obat analgesik, antipiretik, dan antiinflamasi yang banyak dikonsumsi oleh masyarakat. Pemakaian aspirin mempunyai efek samping bila dosisnya besar dan dalam waktu yang lama. ${ }^{1}$ Efek samping yang bisa terjadi antara lain: gastritis, tukak lambung, dan perdarahan lambung. Gastritis yang terjadi karena aspirin disebabkan oleh iritasi mukosa lambung oleh tablet aspirin yang tidak larut dengan sempurna, penyerapan oleh lambung, atau oleh karena hambatan terhadap prostaglandin. $^{2}$

Pengobatan tradisional dengan bahan tumbuhan telah banyak diteliti dan digunakan dalam pengobatan gastritis. Cabe rawit (Capicum frustescens L.) merupakan salah satu tumbuhan yang di gunakan sebagai obat tradisional pada berbagai penyakit termasuk gastritis. Secara umum cabe rawit memiliki banyak manfaat antara lain sebagai bahan bumbu dalam masakan, ramuan obat tradisional, antibiotik, anti alergi, anti radang, dan anti virus. Zat-zat yang terkandung dalam cabe rawit yaitu flavonoid dan kapsaisin. Flavonoid merupakan senyawa yang memiliki aktifitas antioksidan dan sifat kapsaisin yang larut dalam lemak memudahkan kapsaisin menembus taut kedap yang dibentuk oleh membran epitel yang melapisi mukosa lambung. ${ }^{3}$

Penelitian ini bertujuan untuk mengetahui pengaruh pemberian cabe rawit terhadap gambaran histopatologik lambung tikus wistar yang diinduksi aspirin.

\section{METODE PENELITIAN}

Jenis penelitian ini ialah eksperimental yang dilakukan pada bulan Oktober 2015 sampai Februari 2016 di Laboratorium Patologi Anatomi Fakultas Kedokteran Universitas Sam Ratulangi Manado. Subjek penelitian ialah 25 ekor tikus wistar dewasa yang dibagi menjadi 5 ekor tikus untuk control negatif dan 20 ekor tikus untuk perlakuan.

Kelompok perlakuan terdiri dari empat kelompok, yaitu: kelompok B yang diberi asprin selama 10 hari; kelompok $C$ yang diberi aspirin $21 \mathrm{mg}$ bersama-sama dengan cabe rawit 84mg selama 10 hari; kelompok D yang diberi aspirin 21mg selama 10 hari dilanjutkan dengan cabe rawit $84 \mathrm{mg}$ selama 3 hari; dan kelompok E yang diberi aspirin 21mg selama 10 hari diterminasi pada hari ke-14.

Aspirin sebanyak 21mg digerus sampai menjadi serbuk kemudian dilarutkan dalam air sebanyak $1,25 \mathrm{ml} .^{4}$ Cara pemberian menggunakan sonde lambung dimasukan secara hati-hati melalui mulut sampai mencapai lambung. Cabe rawit yang diberikan ialah $84 \mathrm{mg} /$ tikus/hari. ${ }^{4}$ Cabe rawit diblender (dijus) kemudian diberikan menggunakan sonde lambung secara hatihati melalui mulut sampai mencapai lambung tikus.

\section{HASIL PENELITIAN \\ Kelompok A}

Pada kelompok ini diperoleh gambaran mikroskopik lambung tikus sesuai dengan gambaran lambung normal (Gambar 1).

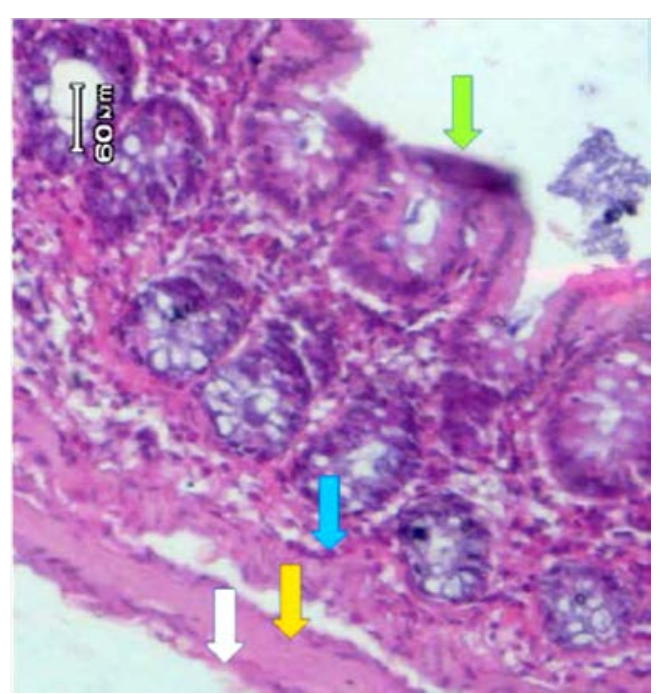

Gambar 1. Gambaran mikroskopik lambung tikus wistar kontrol negatif pembesaran 40x10. (Panah hijau: lapisan mukosa; panah biru: lapisan submukosa; panah kuning: lapisan muskularis; panah putih: lapisan serosa). (pembesaran $40 \times 10$ ).

\section{Kelompok B}

Pada tikus wistar kelompok ini 
diperoleh gambaran mikroskopik dengan infiltrasi sel-sel radang PMN dari mukosa sampai submukosa (Gambar 2).

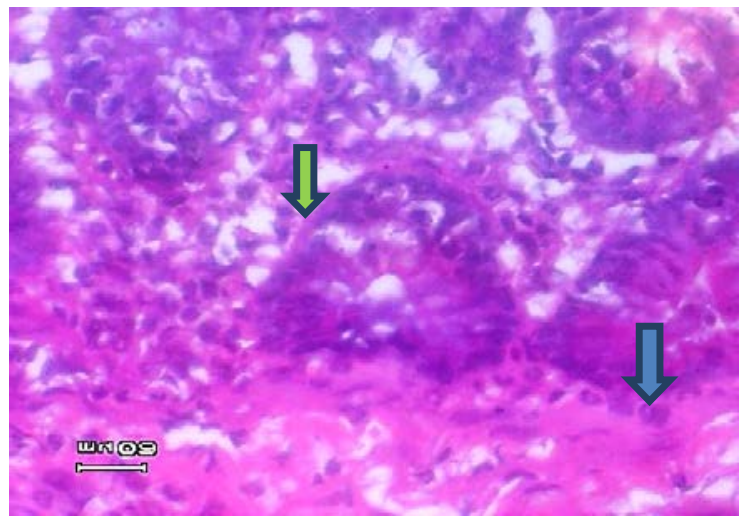

Gambar 2. Gambaran mikroskopik lambung tikus wistar yang diberi aspirin selama 10 hari terdapat infiltrasi sel radang PMN dari mukosa (panah hijau) sampai submukosa (panah biru) (pembesaran $40 \times 10$ ).

\section{Kelompok C}

Pada tikus Wistar kelompok ini diperoleh gambaran mikroskopik dengan sel radang PMN pada mukosa dan sebagian permukaan epitel sudah terjadi erosi (Gambar 3).

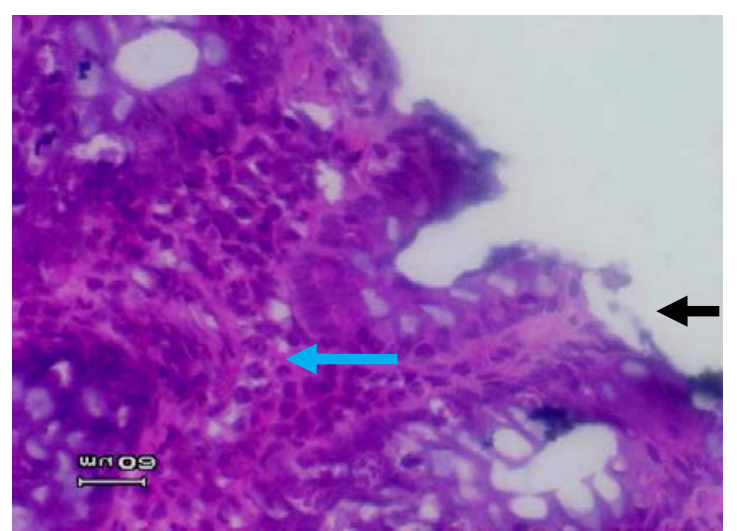

Gambar 3. Gambaran mikroskopik lambung tikus wistar yang diberi aspirin 21mg selama 10 hari bersama-sama dengan cabe rawit $84 \mathrm{mg}$ dengan dosis sekali sehari. Tampak infiltrasi sel-sel radang PMN pada mukosa sampai submukosa (panah biru) dan sudah terjadi erosi pada epitel mukosa (panah hitam) (pembesaran $40 \times 10$ ).

\section{Kelompok D}

Pada tikus wistar kelompok ini diper- oleh gambaran mikroskopik dengan sel radang PMN pada mukosa sampai submukosa tetapi tidak terjadi erosi (Gambar 4).

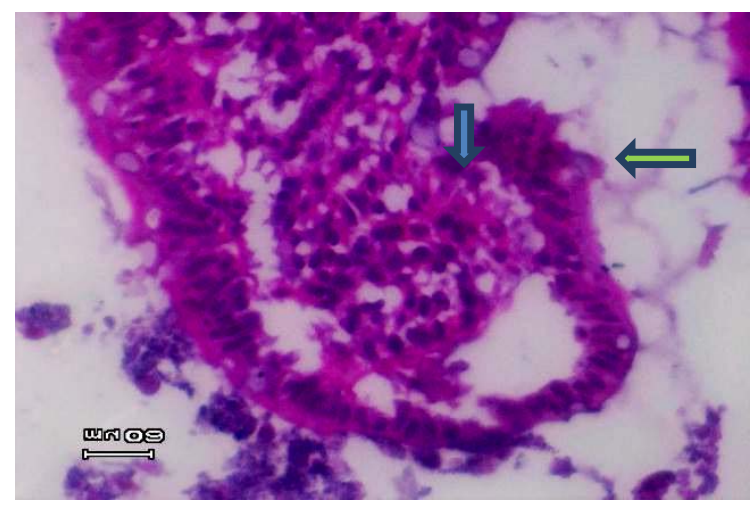

Gambar 4. Gambaran mikroskopik lambung tikus wistar yang diberi aspirin 21mg selama 10 hari dilanjutkan dengan cabe rawit 84mg dengan dosis 2 kali sehari selama 3 hari. Tampak infiltrasi sel-sel radang PMN pada submukosa (panah biru) dan tidak terjadi erosif pada epitel mukosa (panah hijau) (pembesaran $40 \times 10$ ).

\section{Kelompok E}

Pada tikus wistar kelompok ini diperoleh gambaran mikroskopik dengan sedikit radang PMN pada mukosa dan submukosa (Gambar 5).

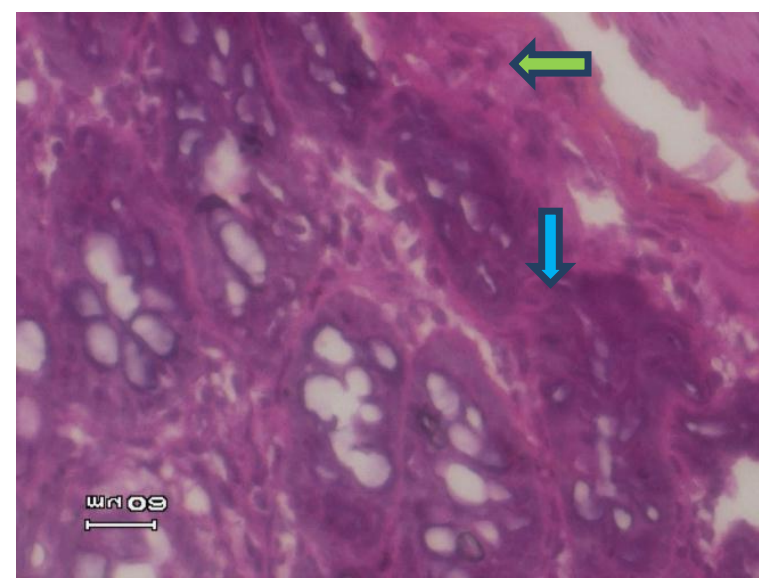

Gambar 5. Gambaran mikroskopik lambung tikus wistar yang diberi aspirin $21 \mathrm{mg}$ selama 10 hari, diterminasi pada hari ke-14. Tampak sedikit radang PMN pada mukosa (panah hijau) dan submukosa (Panah biru) (pembesaran $40 \mathrm{x}$ 10). 


\section{BAHASAN}

Lambung merupakan organ yang berfungsi sebagai tempat penyimpanan dan pencampuran makanan sehingga lambung sangat rentan terhadap bahan-bahan iritan seperti obat-obat dan alkohol. $^{5}$ Hasil penelitian pada kelompok A (kontrol negatif) menunjukkan gambaran macroskopik dan mikroskopik yang sesuai dengan lambung normal (Gambar 1).

Pada kelompok B yang diberikan aspirin 21mg/hari selama 10 hari gambaran makroskopik lambung tampak agak pucat. Hal ini disebabkan aspirin menghambat sintesis prostaglandin sehingga aliran darah pada daerah mukosa dan submukosa menjadi terganggu sedangkan pada gambaran mikroskopiknya terdapat banyak sel-sel radang di lapisan mukosa sampai submukosa (Gambar 2). Aspirin menghambat sintesis prostaglandin melalui penghambatan enzim siklooksigenase-1, yang mengakibatkan penghambatan sintesis PGE2. Prostaglandin juga berfungsi mengatur sekresi asam lambung dan sebagai pertahanan (sitoprotektif) terhadap mukosa lambung. Bila sintesis PGE2 terhambat maka aliran darah mukosa terganggu dan hilangnya lapisan mukus yang melindungi mukosa lambung. Selain itu reaksi radang pada mukosa lambung dapat terjadi juga karena iritasi aspirin pada mukosa lambung. ${ }^{6}$

Pada kelompok C yang diberikan aspirin 21mg selama 10 hari secara bersamaan dengan cabe rawit $84 \mathrm{mg}$, gambaran makroskopik lambung berwarna merah kehitaman. Gambaran microskopiknya memperlihatkan sel-sel radang PMN pada mukosa dan sebagian permukaan epitel terjadi erosi (Gambar 3). Hal ini disebabkan karena cabe rawit dapat bersifat iritan terhadap mukosa lambung dilihat dari rasanya yang pedas meskipun cabe rawit mengandung kapsaisin dan flavonoid sebagai antioksidan.

Pada kelompok D yang diberikan aspirin 21mg selama 10 hari dilanjutkan dengan pemberian cabe rawit selama 3 hari dengan dosis 2 kali 84mg sehari, secara makroskopik tampak warna lambung merah pucat. Pada gambaran mikroskopiknya terdapat sel-sel radang PMN tetapi permukaan epitel tidak terjadi erosi. Hal ini dikarenakan adanya aktifitas antioksidan pada cabe rawit yang menetralkan oksidasi atau menghambat reaksi yang dihasilkan oksigen atau peroksida (Gambar 4).

Kelompok E diberi aspirin 21mg selama 10 hari dan kemudian tidak diberi perlakuan selama 3 hari. Gambaran mikroskopiknya terdapat lebih sedikit selsel PMN pada mukosa dan submukosa lambung dibanding kelompok D. Hal ini disebabkan terjadinya proses regenerasi lambung secara fisiologik (Gambar 5).

\section{SIMPULAN}

Pemberian aspirin 21mg/hari selama 10 hari menyebabkan gastritis akut pada tikus Wistar. Pemberian aspirin bersama cabe rawit $84 \mathrm{mg} /$ hari menyebabkan gastritis akut erosi sedangkan pemberian cabe rawit $168 \mathrm{mg} /$ hari setelah diberi aspirin menyebabkan gastritis akut tanpa erosi.

\section{DAFTAR PUSTAKA}

1. Wilmana PF, Sulistia G, Analgesikantipiretik, anti-inflamasi nonsteroid dan obat gangguan sendi lainnya. In: Gunawan, Nafrialdi SR, editor. Farmakologi dan Terapi (5th ed). Jakarta: Balai Penerbit FKUI, 2007; p. 234-7.

2. Tarihi B, Tarihi K. Biological activities of Musa Species. Br J Pharmac. 2001; 30 p. 39-50.

3. Kurniati E, Mursyanti E, Purwijantiningsih LME. Combination of MS nutrient level and plant growth regular for callus induction and capsaisin production. [Cited 2015 Oct 4]. Available from: http://ejournal.uajy.ac.id/4834/1

/JURNAL.pdf.

4. Teng P, Kairupan C, Loho L. Gambaran histopatologi lambung tikus Wistar yang diberi cabe rawit. eBM. 2013;1(3).

5. Loho L. Patologi Saluran Cerna. Manado: Bagian Patologi Anatomi Fakultas Kedokteran Unsrat, 2002; p. 21. 